\title{
Mycoflora of ergot (Claviceps purpurea) sclerotia as a source of potential biocontrol agents of phytopathogens
} Neshumaeva N.A., Timina M.A.

Krasnoyarsk Agricultural Research Institute, Federal Research Center "Krasnoyarsk Scientific Center of the SB of the RAS”, Krasnoyarsk, Russia

E-mail: nneshumaeva@list.ru

Key message. Mycoflora of sclerotia Claviceps purpurea was studied for identify potential agents of biocontrol of ergot cereals. The genera of micromycetes Penicillium, Alternaria, Mucor, Aspergillus, Fusarium, Rhizopus, Bipolaris, Gliocladium, Epicoccum, Trichoderma were isolated.

Keywords: ergot, Claviceps purpurea, biocontrol

Ergot is a disease of cereals and wild cereals caused by the micromycete Claviceps purpurea (Fr.) Tul. Its sclerotia, contained in grain and hay, can cause poisoning, thereby causing great harm to animals and humans. There are no varieties of cereals that are resistant to ergot, as well as effective fungicides to combat it as of today. The solution to this problem may be the development and use of biopreparations based on hyperparasites of $C$. purpurea. Mycoflora of sclerotia ergot rye was studied. For this, ergot horns after surface sterilization and flaming were placed to Petri dishes on the surface of potato-sucrose agar with the addition of Triton X-100 and incubated at a temperature of $22{ }^{\circ} \mathrm{C}$ for $7-14$ days until colonies appeared. The following were tested as sterilizing agents: $95 \%$ ethyl alcohol; $70 \%$ ethyl alcohol, $5 \%$ sodium hypochloride ( $\mathrm{NaOCl}$ ) and $70 \%$ ethyl alcohol, $5 \% \mathrm{NaOCl}$. Micromycetes were isolated in pure cultures and identified by morphological and cultural characteristics. In total, 728 sclerotia collected from plants of rye varieties of the Krasnoyarsk selection Yeniseika, Krasnoyarskaya universalnaya, and Mininskaya were examined. As a result of selection, sterilization of $5 \% \mathrm{NaOCl}$ was recognized as the best option. In the mycobiota of sclerotia, representatives of mold storage prevailed. The composition of mycobiota fungi (in \% of sclerotia contaminated by this genus) was as follows: Penicillium $\neg 44.4 \%$, Alternaria - 30.0\%, Mucor - 12.5\%, Aspergillus - 5.5\%, Fusarium - 4.4\%, and also Rhizopus, Bipolaris, Gliocladium, Epicoccum, Trichoderma less than $1.0 \%$. In many cases, cohabitation of two or three micromycetes on one sclerotia was noted. The antagonistic properties of isolated promising isolates of the genera Trichoderma, Gliocladium were studied.

\section{Микофлора склероциев спорыньи (Claviceps purpurea), как источник потенциальных агентов биоконтроля фитопатогенов \\ Нешумаева Н.А., Тимина М.А.}

Красноярский научно-исследовательский институт сельского хозяйства, Федеральный исследовательский центр «Красноярский научный центр СО РАН», Красноярск, Россия

\begin{abstract}
Аннотация. Исследована микофлора склерочиев Claviceps ригригеа для выявления потенциальных агентов биоконтроля спорыньи зерновых культур. Изолированные микромицеть принадлежали к родам Репісіlliuт, Alternaria, Mucor, Aspergillus, Fusarium, Rhizopus, Bipolaris, Gliocladium, Epicoccum, Trichoderma.
\end{abstract}

Ключевые слова: Спорынья, Claviceps ригритеа, биоконтроль

Спорынья - заболевание зерновых культур и дикорастущих злаков, вызываемое микромицетом Claviceps purpurea (Fr.) Tul. Его склероции, содержащиеся в зерне и сене, могут вызывать отравления, тем самым нанося большой вред животным и человеку. На сегодняшний день отсутствуют сорта зерновых культур резестентные к спорынье, так же как и эффективные фунгициды для борьбы с ней. Решением данной проблемы может стать разработка и использование биопрепаратов, созданных на основе гиперпаразитов C. purpurea. В работе исследовали микофлору склероциев спорыньи ржи. Для этого рожки спорыньи после поверхностной стерилизации и фламбирования раскладывали в чашки Петри на поверхность картофельно-сахарозного агара с добавлением Triton X-100 и инкубировали при температуре $22^{\circ} \mathrm{C}$ в течение 7-14 суток до появления колоний. В качестве стерилизующих агентов были опробованы следующие: 95\% этиловый спирт; 70\% этиловый спирт, 5\% гипохлорид натрия (NaOCl) и $70 \%$ этиловый спирт, 5\% $\mathrm{NaOCl}$. Микромицеты выделяли в чистые культуры и идентифицировали по морфологокультуральным признакам. Всего было исследовано 728 склероциев, собранных с растений сортов ржи красноярской селекции Енисейка, Красноярская универсальная, Мининская. В результате подбора лучшим вариантом признана стерилизация 5\% $\mathrm{NaOCl}$ В микобиоте склероциев превалировали представители плесеней хранения. Состав грибной микобиоты (в \% склероциев, контаминированных данным родом) оказался следующим: Penicillium 44,4\%, Alternaria - 30,0\%, Mucor - 12,5\%, Aspergillus - 5,5\%, Fusarium - 4,4\%, а также Rhizopus, Bipolaris, Gliocladium, Epicoccum, Trichoderma - менее $1,0 \%$. Во многих случаях отмечали совместное обитание на одном склероции двух или трех микромицетов. Были изучены антогонистические свойства выделенных перспективных изолятов родов Trichoderma, Gliocladium. 